\title{
Public Expenditures on Social Programs and Household Consumption in China
}

Emanuele Baldacci, Giovanni Callegari, David Coady, Ding Ding, Manmohan Kumar,

Pietro Tommasino, and Jaejoon Woo 


\title{
IMF Working Paper
}

Fiscal Affairs Department

\section{Public Expenditures on Social Programs and Household Consumption in China \\ Prepared by Emanuele Baldacci, Giovanni Callegari, David Coady, Ding Ding, Manmohan Kumar, Pietro Tommasino, and Jaejoon Woo ${ }^{1}$}

Authorized for distribution by Manmohan Kumar

March 2010

\begin{abstract}
This Working Paper should not be reported as representing the views of the IMF. The views expressed in this Working Paper are those of the author(s) and do not necessarily represent those of the IMF or IMF policy. Working Papers describe research in progress by the author(s) and are published to elicit comments and to further debate.

This paper shows that increasing government social expenditures can make a substantive contribution to increasing household consumption in China. The paper first undertakes an empirical study of the relationship between the savings rate and social expenditures for a panel of OECD countries and provides illustrative estimates of their implications for China. It then applies a generational accounting framework to Chinese household income survey data. This analysis suggests that a sustained 1 percent of GDP increase in public expenditures, distributed equally across education, health, and pensions, would result in a

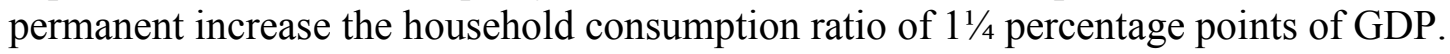

JEL Classification Numbers:D12, E21, H31

Keywords: China, household savings, social expenditure, generational accounting Authors’ E-Mail Addresses: dcoady@imf.org, mkumar@imf.org

${ }^{1}$ Baldacci, Callegari, Coady, Ding, Kumar, and Woo are all staff members at the Fiscal Affairs Department of the IMF. Tommasino is an economist at the Research Department of the Bank of Italy. We have benefitted greatly from comments received at the 2009 Asian Development Bank Institute Annual Conference in Japan, at a 2010 IMF Workshop in Beijing, and from Benedict Clements, Carlo Cottarelli, Sanjeev Gupta, and other IMF staff.
\end{abstract}




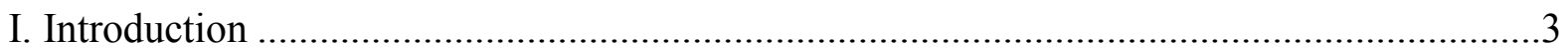

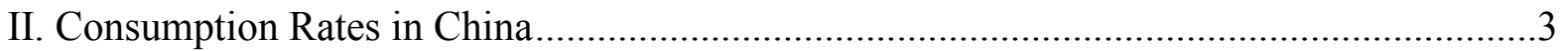

III. Impact of Public Social Expenditures on Household Saving: Panel Analysis ...................7

IV. Assessing Impact of Expanding Social Programs in China: Methodology and Data........12

V. Assessing the Impact of Expenditure Reforms .................................................... 17

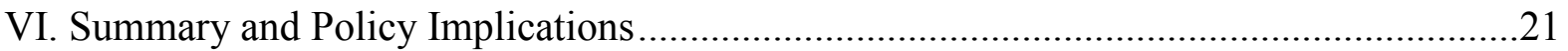

Tables

1. Household Saving Panel Regression, 1990-2008 (OECD) .......................................... 10

2. Impact on Household Saving ................................................................................. 11

Figures

1. Private Consumption Expenditure in China .........................................................

2. Private Consumption Expenditure in Asia.....................................................................4

3. Average Propensities to Consume Out of Lifetime Income ..........................................16

Boxes

1. Determinants of Household Savings Rate: Survey of Evidence.......................................6

2. Methodology for Estimating Consumption Impact of Social Expenditures .......................13

3. Constructing Lifetime Income and Average Propensities to Consume .............................15

Appendix Tables

3. Individual Component of Public Expenditures ...............................................................23

4. Consumption Shares of Various Consumption Categories.............................................23

5. Per Capita Transfers under Different Social Expenditure Reforms.................................24

6. Per Capita Transfers and Consumption ..................................................................25

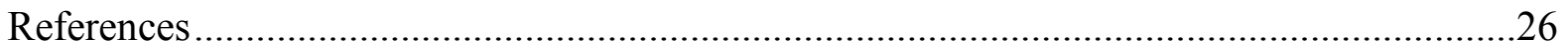




\section{INTRODUCTION}

Household consumption in China is low. The ratio of household consumption to GDP is only 37 percent, compared to close to or above 50 percent of GDP in industrial and emerging market countries. This in part reflects China's specific growth model, and a high level of precautionary savings. The latter may be due largely to inadequate social protection programs relating to health and old age, and the elevated private cost of higher education. Additional factors relate to demographic trends and inadequate access to credit for a significant share of the population. This low propensity to consume and the associated high savings rate have received significant attention in domestic and international policy circles and are viewed as a key element in China's large current account surpluses and the associated global imbalances.

This paper examines the likely impact of expanding social programs on household consumption in China. It identifies a variety of channels through which higher government social spending can impact household consumption and quantifies the likely effects. Specifically, it explores the following three channels: (i) household age-specific propensities to consume out of (lifetime) disposable income; (ii) the distribution of household disposable income across different income groups (with different propensities to consume); and (iii) the overall level of household disposable income. Using household income survey data, the paper applies a generational accounting framework to estimate the age-specific marginal propensities to consume for different income groups and the lifetime amount of resources available to each cohort. The model is used to simulate the effects on aggregate consumption of alternative government social expenditure reforms.

The rest of the paper is organized as follows: Section II provides an overview of trends in consumption and savings in China and discusses the underlying determinants. Section III presents new evidence on the impact of public expenditures on health, education, and pensions on savings rates for a panel of industrial and emerging market countries. Section IV describes the methodology and data used in estimating the impact of social program reforms in China. Simulation analysis exploring the impact of a range of social expenditure reforms is

presented in Section $\mathrm{V}$. The final section provides a summary of the results and discusses the policy implications.

\section{CONSUMPTION RATES IN ChINA}

Household consumption as a share of GDP in China is low and has been falling. The ratio of household consumption to GDP was 37 percent in 2008, having fallen almost continuously from about 55 percent in 1981 (Figure 1). The current ratio ranks China at the bottom in the Asian region as well as among emerging markets. With regard to its evolution over time, in Asia only India has witnessed a similar decline in the consumption ratio, but starting from a much higher level (Figure 2). The level of household consumption in China is low also in comparative historical terms. For instance, China's consumption ratio is lower 
than that in the U.S. in the 1850s, when its GDP per capita was comparable with that of China today (McKinsey 2009).

Figure 1. Private Consumption Expenditure in China

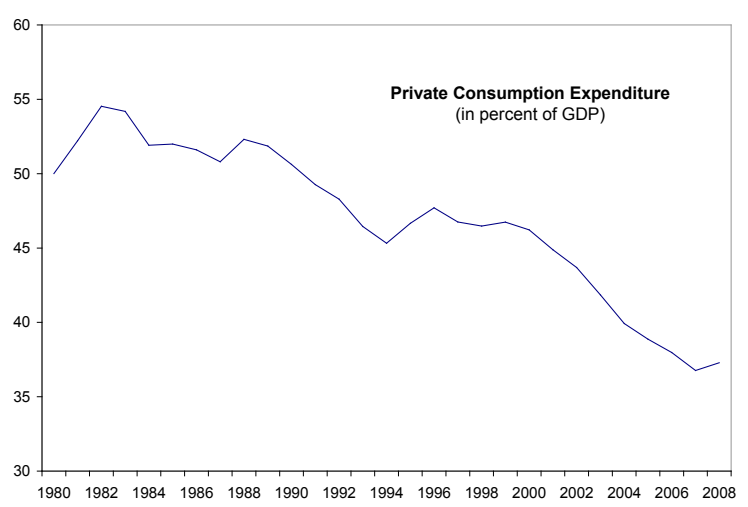

Figure 2. Private Consumption Expenditure in Asia

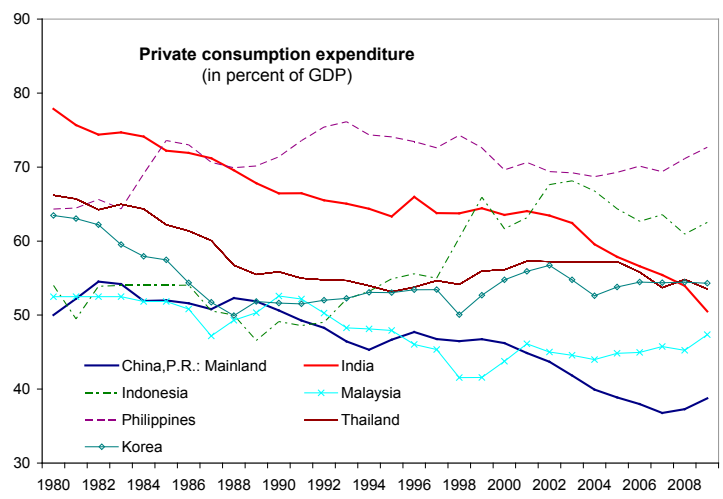

The decline in the household consumption ratio can be split into two components, reflecting changes in the savings rate and in the share of household income in GDP:

- The household savings rate in China is high and has been gradually increasing. The average savings rate of households out of disposable income rose from 11 percent in 1990 to 25 percent in 2007, 12 percentage points higher than the Asian average. This contrasts with the decline observed in other Asian countries, with the exception of India (McKinsey 2009). China's household savings rate is high also when compared with industrial countries: in 2007, the average household savings rate of EU countries was about 11 percent, while in the US it was below 2 percent (Leetmaa and others 2009).

- China's household disposable income as a share of GDP is low at about 54 percent, and has declined by about 8 percentage points between 1990 and 2007.

Overall, the increase in the household savings rate accounts for about 9 percentage points of the approximately 13 percentage points of GDP decline in the household consumption ratio between 1990 and 2007. The rest can be explained by the fall in the share of household disposable income in GDP over the same period.

The decline in household income as a share of GDP can be explained by weak wage growth and limited redistribution of firms' profits. Weak wage growth reflects a variety of factors: high internal migration from rural to urban areas has maintained a high supply of labor which outstrips the increase in demand, resulting in a sizeable under- or unemployed share of labor. This is combined with the absence of effective union organizations and some degree of monopsonistic power in the hands of employers. Investment income has languished 
because of the virtual absence of profit redistribution to the public. This is due to the limited number of publicly listed firms and the tendency of State-Owned Enterprises (SOEs) not to pay dividends to the government, which could be redistributed to the public.

The increase in the household savings rate reflects a number of factors. According to the life-cycle hypothesis, consumption and saving depend mainly on lifetime resources (net present value of income plus net current wealth) and on the demographic structure of the population. These two factors impact the savings rate differently: expected future growth of income reduces current savings; conversely, an increase in the ratio of working to nonworking population can increase the savings rate, given the higher average income resulting from a greater proportion of population being employed. In contrast to the life-cycle hypothesis, the "precautionary" savings explanation postulates that higher income and expenditure risks may increase savings, as households save to deal with adverse shocks. This would be consistent with an increasing savings rate with age.

\section{Each of the above factors appears to have characterized the Chinese economy at various times during the last two decades. Rapid economic growth has taken place} throughout the entire period together with an increase in the share of working population.

At the same time, reform of the SOEs at the beginning of the 1990s substantially reduced the coverage of China's effective "welfare" state. According to the system operated by the SOEs, the "work unit" was responsible for the social and economic welfare of workers and their families. After the reform of the SOEs, the burden of health and education expenditures essentially shifted to the private sector, thus effectively reducing households' lifetime incomes (as income in kind was lowered by the reforms), and also leading to a perception of higher income and expenditure risk. The increased risk faced by households of incurring significant health or education expenditures is thus likely to have played a role in the rise in the savings rate.

\section{Recent analysis confirms that savings for health and education costs play an important role in explaining the increase in the household savings rate. Earlier studies on the} relation between saving and lifetime income (Kraay 2000, Modigliani and Cao 2004, and Horioka and Wan 2006), lent some support to the role of demographic factors in explaining the dynamics of the savings rate (see Box 1). These conclusions, however, have been questioned by more recent estimates on the age profile of the savings rate by Chamon and Prasad (2008), showing a U-shaped age profile of savings in which younger and older households save relatively more. The same study shows that households featuring high expenditure risk on health (typically the older households) tend to have a savings rate 20 percentage points higher than household not facing these risks. Similarly, households with small children tend to have a savings rate up to 5 percentage points higher than households without, in order to save to finance future education spending. These effects may have been 
amplified by financial underdevelopment, as reflected in constraints on borrowing against future income and low returns on financial assets. ${ }^{2}$

\begin{tabular}{|c|c|c|c|}
\hline \multicolumn{4}{|c|}{ Box 1. Determinants of Household Savings Rate: Survey of Evidence } \\
\hline Authors & Data source or country & Sample & Empirical findings \\
\hline \multicolumn{4}{|c|}{ China, determinants of households' savings rate: } \\
\hline Kraay (2000) & $\begin{array}{l}\text { Rural and urban household survey } \\
\text { of China's National Bureau of } \\
\text { Statistics (NBS) }\end{array}$ & 1978-1995 & $\begin{array}{l}\text { Expectations of future income growth and the role of } \\
\text { subsistence consumption play an important role in } \\
\text { determining rural household saving levels. No } \\
\text { significant relationship explaining urban saving levels. }\end{array}$ \\
\hline $\begin{array}{l}\text { Modigliani and Cao } \\
\text { (2004) }\end{array}$ & $\begin{array}{l}\text { Aggregate data from the China } \\
\text { Statistical Yearbook }\end{array}$ & $1953-2000$ & $\begin{array}{l}\text { Savings rate increases with the share of working age } \\
\text { population, in line with the life-cycle hypothesis. }\end{array}$ \\
\hline $\begin{array}{l}\text { Horioka and Wan } \\
(2006)\end{array}$ & $\begin{array}{l}\text { Province-level data from China } \\
\text { Statistics Yearbook }\end{array}$ & 1996-2005 & $\begin{array}{l}\text { Demographic factors affect savings in line with the life- } \\
\text { cycle hypothesis; Savings rate across time and provinces } \\
\text { determined mainly by the lagged savings rate, income } \\
\text { growth, interest rate and, in some cases, inflation. }\end{array}$ \\
\hline $\begin{array}{l}\text { Chamon and Prasad } \\
(2008)\end{array}$ & Urban household surveys (NBS) & $1990-2005$ & $\begin{array}{l}\text { Virtual absence of consumption smoothing over time. } \\
\text { Savings rates of younger and older households have } \\
\text { grown relatively more; the factor that best explains these } \\
\text { patterns is the rising private expenditure on health, } \\
\text { education, and housing. }\end{array}$ \\
\hline $\begin{array}{l}\text { Wei and Zhang } \\
\text { (2009) }\end{array}$ & $\begin{array}{l}\text { China population census, County } \\
\text { social and economic statistical } \\
\text { yearbook } 2000 \text {, Chinese household } \\
\text { income project }\end{array}$ & 2002 & $\begin{array}{l}\text { Half of the increase in the household savings rate can be } \\
\text { explained by the increasing share of males in the } \\
\text { population, experienced after the adoption of the one- } \\
\text { child policy. The premise is that males save to } \\
\text { accumulate assets that would put them at a competitive } \\
\text { advantage when searching for a spouse. }\end{array}$ \\
\hline $\begin{array}{l}\text { Barnett and Brooks } \\
(2010)\end{array}$ & China provincial data from CEIC & $1994-2007$ & $\begin{array}{l}\text { Spending on health, but not education, had an impact on } \\
\text { household behavior. A one yuan increase in government } \\
\text { health spending is associated with a two yuan increase in } \\
\text { urban household consumption. }\end{array}$ \\
\hline \multicolumn{4}{|c|}{ Other countries, impact of extending social safety nets on savings: } \\
\hline Kotlikoff (1989) & USA & $1950-1987$ & $\begin{array}{l}\text { Savings rate is negatively correlated with the availability } \\
\text { of public health insurance. }\end{array}$ \\
\hline $\begin{array}{l}\text { Kantor and } \\
\text { Fishback (1996) }\end{array}$ & USA & $1917-1919$ & $\begin{array}{l}\text { The introduction of workers' compensation following } \\
\text { injuries at work (gradually introduced from } 1917 \text { to } \\
\text { 1919) reduced private savings by approximately } 25 \\
\text { percent of their baseline value. }\end{array}$ \\
\hline $\begin{array}{l}\text { Gruber and } \\
\text { Yelowitz (1999) }\end{array}$ & USA & $1984-1993$ & $\begin{array}{l}\text { Among the population eligible for Medicaid in } 1993 \text {, } \\
\text { each } \$ 1,000 \text { of added coverage would increase } \\
\text { household consumption by } \$ 538 \text {. }\end{array}$ \\
\hline $\begin{array}{l}\text { Chou, Liu and } \\
\text { Hammitt (2006) }\end{array}$ & Taiwan & 1992-1997 & $\begin{array}{l}\text { The extension of health insurance coverage decreased } \\
\text { the households' savings rate by } 3-10 \text { percent; this means } \\
\text { that an increase in health expenditures of } 1 \text { percentage } \\
\text { point of GDP increased current household consumption } \\
\text { by } 0.4-0.6 \text { percent of GDP. }\end{array}$ \\
\hline
\end{tabular}

\footnotetext{
${ }^{2}$ In line with the age profile estimated by Chamon and Prasad (2008), Wei and Zhang (2009) found that half of the increase in the household savings rates can be explained by the increasing share of males in the population, experienced after the adoption of the one-child policy.
} 
Other country-specific evidence also supports the premise that extending social services is likely to increase the household consumption rate. A number of studies have been undertaken on the impact of extending social services (including health, education and pension insurance) on consumption for the U.S. These suggest a positive relationship between the extension of social services and households' consumption rates. For instance, Gruber and Yelowitz (1999) found that, among the population eligible for Medicaid in 1993, each US $\$ 1,000$ of added coverage increased household consumption by US\$538. Chou, Liu, and Hammitt (2006) examined the extension of Taiwan's health insurance coverage from 57 percent of the population in 1994 to 96 percent in 2000, and concluded that the reform decreased savings by 3-10 percent, and that a one dollar increase in medical care transfer payments reduced savings by US\$0.4-0.6. This result is interpreted as indicating specifically the impact of health insurance on savings, as changes in household income or in the age of the households are explicitly controlled for in the analysis.

\section{Impact of Public Social Expenditures on Household Saving: Panel} ANALYSIS

This section presents new evidence on the relationship between household saving and government social expenditures. The empirical analysis is based on a panel of 24 OECD countries over 1990-2008. ${ }^{3}$ As noted above, the empirical evidence from household budget surveys suggests that government spending on health care, education, and pensions may be associated with lower household savings. However, there are very few studies that assess the significance and size of these effects for a panel of countries (the main exception appears to be Barrell and others 2009). This section fills this gap in the literature. The results can be used to obtain illustrative estimates of the potential impact on household consumption of raising social spending in China. More specific results for China based on simulations using household budget survey data are presented in the next two sections.

\section{Analytical framework}

The analysis below draws on the well-established theoretical and empirical literature on the determinants of savings. Real per capita income and its growth rate, demographic factors, and financial system development are the main determinants of cross-country variations in household savings over time (Loayza and others 2000, IMF 2005, Bosworth and Chodorow-Reich 2007, and Park and Shin 2009, among others). ${ }^{4}$ Building on this literature,

\footnotetext{
${ }^{3}$ The focus is on the long-run relationship between saving and its potential determinants. Data are 5 -year averages; the availability of public expenditure data dictates the length of the time period. Household saving data are obtained from OECD (2009a) and social expenditure data from OECD (2009b). Data on real per capita income and growth are from Heston and others (2009), demographic variables from World Bank (2009), and financial development measure from Beck and others (2000, update 2007).

${ }^{4}$ Most cross-country studies examine national or private saving, rather than household saving. As a robustness check, we have also estimated models using data on gross domestic saving (available from World Bank 2009)
}

(continued...) 
a standard set of explanatory variables is considered, including economic and demographic factors, and financial system variables. It is in this framework that the impact of government spending on health care, education (primary, secondary, and higher), and social security (pensions and social assistance) on the savings rate is explored.

\section{The baseline regression specification for household saving as a percent of disposable income is as follows: ${ }^{5}$}

$$
\text { Saving }_{i t}=\alpha+\mathbf{X}_{i t}{ }^{\prime} \beta+\gamma Z_{i t}+v_{i}+\varepsilon_{i t}
$$

where $i$ and $t$ denote the country and time period; $v_{i}$ is the country-specific fixed effect; $\varepsilon_{i t}$ is an error term; $\mathbf{X}_{i t}$ is a vector of economic, financial and demographic variables; $Z_{i t}$ is the social spending variable (in percent of GDP).

$\mathbf{X}_{i t}$ includes the following:

- $\quad$ Real per capita GDP and its growth: richer countries tend to save more than poorer countries and fast-growing countries tend to save more than slow-growing countries;

- Demographic structure: which is captured by two dependency ratios, old age-dependency (ratio of the population aged 65 years and above to that aged 15-64 years) and young age-dependency rates (ratio of the population under 15 years to that aged 15-64 years). Existing empirical evidence suggests that a high old age-dependency ratio is associated with lower aggregate saving, as the number of dissavers is greater than the number of savers based on the life-cycle theory. On the other hand, high dependency rates can have adverse implications for public savings under a PAYG system; and

- $\quad$ Financial development, as measured by credit extended to the private sector from banks and other financial institutions (as percent of GDP). An underdeveloped financial system can lead to higher savings (Prasad 2009). ${ }^{6}$ In a growing economy where the desired consumption bundle shifts towards durable goods, the inability to

and private saving (available from Bosworth and Chodorow-Reich 2007). The results were qualitatively similar to those presented in the text.

${ }^{5}$ The two main estimation methods reported are fixed-effects panel and dynamic panel GMM regression. The results from different estimation methods including pooled OLS (not reported) are broadly similar. Focusing on different time periods or including the time trend or time fixed effects does not alter the results.

${ }^{6}$ Caballero and others (2008) identify financial underdevelopment as an important determinant of rising saving and hence as a driver of global imbalances. However, Edwards (1996) argues that financial deepening induces higher saving by creating more sophisticated financial systems. 
borrow against future income streams could lead households to save more in order to self-finance their purchases.

\title{
Empirical results
}

\begin{abstract}
Higher government social spending is generally found to be associated with lower household saving. The estimated effect is non-linear, implying that the marginal reduction in saving in response to an increase in social spending is largest when the level of social spending (as a percent of GDP) is low (Table 1). As spending levels rise, the marginal decline in savings from increased public spending becomes smaller. The coefficients for social spending are statistically significant and economically meaningful. Not surprisingly, the magnitude of the marginal impact of social spending on household saving differs across spending items and depends on the initial spending level (reflecting the non-linear relationship). Public spending on health care has the largest negative impact. The effect of spending on social security is somewhat smaller, but significant. Spending on education also seems to have a sizable negative impact, but it is only significant in regressions when individual social spending components are considered separately (Appendix Table 3).
\end{abstract}

The coefficients on total social spending and its squared term suggest a non-linear "U-shaped" relationship: the minimum level of household saving (with respect to total spending) is reached when total social spending is around 31-36 percent of GDP (Columns 1,2 , and 4). The sample mean of social spending is 28.1 percent of GDP. As an illustrative example, consider a country where social spending is at this sample average. Results show that household saving will fall by $0.26-0.45$ percent of household disposable income in response to an increase in total spending by 1 percent of GDP. ${ }^{7}$

As the average household disposable income is about 54 percent of GDP, Columns 1, 2, and 4 suggest that a 1 percent of GDP increase in total social spending is likely to reduce household saving by $0.14-0.24$ percent of GDP.

Alternatively, the impact on saving of a simultaneous increase in spending on each of the three components individually can be computed. This is based on Column 3, and yields a similar impact of around 0.13 percent (of GDP) on household savings for a 1 percent of GDP increase in total spending (assuming $1 / 3$ outlay on each component).

\section{An application of these results to China can provide some illustrative estimates. Given} China's current social spending (around 6 percent of GDP), the marginal reduction in household savings for a 1 percent of GDP increase in social spending could be in the range of $0.56-1.03$ percent of GDP. ${ }^{8}$

\footnotetext{
${ }^{7}$ Column (1): $\Delta$ Saving $/ \Delta Z=0.06 Z-1.95$ because Saving $=0.03 Z^{2}-1.95 Z+$ other terms, where $Z$ is total social spending.

${ }^{8}$ Needless to say, some caution is needed in extrapolating the results based on the OECD country sample for China. The level of economic and institutional development in the sample countries is higher than in China.
} 
Table 1. Household Saving Panel Regression, 1990-2008 (OECD)

Dependent Variable: Household Saving (Percent of household disposable income)

\begin{tabular}{|c|c|c|c|c|}
\hline Explanatory Variables & $\begin{array}{l}\text { (1) } \\
\text { FE }\end{array}$ & $\begin{array}{l}\text { (2) } \\
\text { FE }\end{array}$ & $\begin{array}{l}\text { (3) } \\
\text { FE }\end{array}$ & $\begin{array}{l}(4) \\
\text { System } \\
\text { GMM }\end{array}$ \\
\hline Household saving (lagged) & & & & $\begin{array}{l}-0.41^{*} \\
(-1.73)\end{array}$ \\
\hline Growth, per capita GDP & $\begin{array}{l}-0.40^{\star *} \\
(-2.19)\end{array}$ & $\begin{array}{l}-0.35 \\
(-1.66)\end{array}$ & $\begin{array}{l}-0.27 \\
(-1.13)\end{array}$ & $\begin{array}{l}-0.06 \\
(-0.18)\end{array}$ \\
\hline Initial GDP per capita (log) & $\begin{array}{l}48.19 \\
(0.73)\end{array}$ & $\begin{array}{l}-84.88 \\
(-0.97)\end{array}$ & $\begin{array}{c}190.9^{* *} \\
(2.42)\end{array}$ & $\begin{array}{l}-67.29 \\
(-0.39)\end{array}$ \\
\hline Initial GDP per capita (log), squared & $\begin{array}{l}-2.75 \\
(-0.85)\end{array}$ & $\begin{array}{l}3.93 \\
(0.91)\end{array}$ & $\begin{array}{l}-9.44^{* *} \\
(-2.42)\end{array}$ & $\begin{array}{c}3.5 \\
(0.40)\end{array}$ \\
\hline Private credits & $\begin{array}{c}-1.5 \\
(-1.62)\end{array}$ & $\begin{array}{c}-0.88 \\
(-0.83)\end{array}$ & $\begin{array}{l}-2.19 \\
(-1.63)\end{array}$ & $\begin{array}{l}-4.13^{\star *} \\
(-2.56)\end{array}$ \\
\hline Old-age dependency ratio & $\begin{array}{c}-0.75^{\star * *} \\
(2.92)\end{array}$ & $\begin{array}{c}-0.71^{* * *} \\
(-3.14)\end{array}$ & $\begin{array}{c}-0.46 \\
(-1.31)\end{array}$ & $\begin{array}{l}-1.29^{* *} \\
(-2.48)\end{array}$ \\
\hline Young-age dependency ratio & $\begin{array}{c}-0.27 \\
(-1.18)\end{array}$ & $\begin{array}{c}-0.21 \\
(-0.97)\end{array}$ & $\begin{array}{c}0.15 \\
(0.49)\end{array}$ & $\begin{array}{c}0.26 \\
(0.51)\end{array}$ \\
\hline Public social spending, total ${ }^{1}$ & $\begin{array}{c}-1.95^{\star * *} \\
(-4.17)\end{array}$ & $\begin{array}{c}-2.14^{* * *} \\
(-4.43)\end{array}$ & & $\begin{array}{c}-3.66^{* * *} \\
(-2.92)\end{array}$ \\
\hline Public social spending total, squared & $\begin{array}{c}0.03^{* * *} \\
(4.14)\end{array}$ & $\begin{array}{c}0.03^{* * *} \\
(4.12)\end{array}$ & & $\begin{array}{c}0.06^{* * *} \\
(2.9)\end{array}$ \\
\hline Government saving & & $\begin{array}{l}-0.33^{\star *} \\
(-2.52)\end{array}$ & & \\
\hline Public health spending & & & $\begin{array}{c}-6.84^{* * *} \\
(-3.45)\end{array}$ & \\
\hline Public health spending, squared & & & $\begin{array}{c}0.44^{* * *} \\
(4.09)\end{array}$ & \\
\hline Public education spending & & & $\begin{array}{l}2.33 \\
(0.67)\end{array}$ & \\
\hline Public education spending, squared & & & $\begin{array}{l}-0.10 \\
(-0.52)\end{array}$ & \\
\hline Social protection spending & & & $\begin{array}{l}-2.15^{\star} \\
(-1.81)\end{array}$ & \\
\hline Social protection spending, squared & & & $\begin{array}{l}0.05^{*} \\
(1.84)\end{array}$ & \\
\hline $\begin{array}{l}\text { Arellano-Bond test for AR(2), p-value } \\
\text { Hansen Test of Joint Validity of instruments } \\
\text { No. of Instruments }\end{array}$ & & & & $\begin{array}{c}0.47 \\
0.95 \\
14\end{array}$ \\
\hline No. of Obs. & 78 & 68 & 78 & 74 \\
\hline No. of countries & 24 & 20 & 24 & 24 \\
\hline$R^{\wedge} 2$ & 0.76 & 0.8 & 0.8 & \\
\hline
\end{tabular}

Note: The panel consists of four 5 -year periods for 24 countries. Heteroskedasticity and country-specific autocorrelation consistent t-statistics are reported in parentheses. Levels of significance are indicated by asterisks: ${ }^{* * *} 1$ percent, ${ }^{* *} 5$ percent, * 10 percent. An intercept term is included in each regression.

${ }^{1}$ Public social spending total is the sum of the public expenditures on health, education, and social protection.

The coefficient on health expenditures (about 2.1) is nearly identical to that obtained by Barnett and Brooks (2010) for the effect of public health spending on savings of urban households in China. 
Depending on the composition of social spending, however, social spending increases will have different impacts. In the sample, for a country whose public health expenditure is at the sample mean of 6.3 percent of GDP, household saving will fall by $0.70-0.78$ percent of GDP in response to an increase in health expenditure by 1 percent of GDP (Column 3 of Table 1, and Column A of Appendix Table 3). ${ }^{9}$ Using China's spending levels and ratio of disposable income to GDP yields an impact of about 2 percent of GDP on household savings for each 1 percent increase in government spending on health. Similarly, a 1 percent of GDP increase in social security spending reduces household saving by $0.22-0.29$ percent of GDP in the sample (evaluated at the sample mean), and 0.68-0.72 percent of GDP in China (Column 3 of Table 1 and Column $\mathrm{C}$ of Appendix Table 3). However, public spending on education is only significant when other social spending components are excluded (Column B, Appendix Table 3). ${ }^{10}$ With this caveat, it appears that a 1 percent of GDP increase in public education spending leads to a decline in household saving by 0.79 percent of GDP in the OECD countries and 1.26 percent of GDP in China. Table 2 provides a summary of the illustrative estimates of the impact on household saving of a 1 percent of GDP increase in government expenditures.

Table 2. Impact on Household Saving

(As percent of GDP) of a 1 Percent of GDP Increase in Government Expenditure

\begin{tabular}{|c|c|c|c|c|}
\hline & $\begin{array}{l}\text { Total Social Spending } \\
\text { Columns (1),(2) and (4) }\end{array}$ & $\begin{array}{c}\text { Health } \\
\text { Columns (3), (A) }\end{array}$ & $\begin{array}{l}\text { Education } \\
\text { Column (B) }\end{array}$ & $\begin{array}{l}\text { Social Security } \\
\text { Columns (3), (C) }\end{array}$ \\
\hline $\begin{array}{l}\text { Marginal reduction } \\
\text { in household saving } \\
\text { in OECD }\end{array}$ & $0.14 \sim 0.24$ & $0.70 \sim 0.78$ & 0.79 & $0.22 \sim 0.29$ \\
\hline $\begin{array}{l}\text { Measured at OECD } \\
\text { average }\end{array}$ & $\begin{array}{l}\text { at } 28.1 \text { percent of GDP } \\
\text { for total social spending }\end{array}$ & $\begin{array}{l}\text { at } 6.3 \text { percent of } \\
\text { GDP for health } \\
\text { spending }\end{array}$ & $\begin{array}{l}\text { at } 5.8 \text { percent of } \\
\text { GDP for education } \\
\text { spending }\end{array}$ & $\begin{array}{l}\text { at } 16.1 \text { percent of } \\
\text { GDP for social } \\
\text { protection }\end{array}$ \\
\hline $\begin{array}{l}\text { Marginal reduction } \\
\text { in household saving } \\
\text { in China } \\
\text { Measured at current } \\
\text { levels in China }\end{array}$ & $\begin{array}{l}0.56 \sim 1.03 \\
\text { at } 6 \text { percent of GDP for } \\
\text { total social spending }\end{array}$ & $\begin{array}{l}2.09 \sim 2.12 \\
\text { at } 0.9 \text { percent of } \\
\text { GDP for health } \\
\text { spending }\end{array}$ & $\begin{array}{c}1.26 \\
\text { at } 2.9 \text { percent of } \\
\text { GDP for education } \\
\text { spending }\end{array}$ & $\begin{array}{l}0.68 \sim 0.72 \\
\text { at } 2.2 \text { percent of } \\
\text { GDP for social } \\
\text { security spending }\end{array}$ \\
\hline
\end{tabular}

Source: Calculations based on Table 1 and Appendix Table 3.

\footnotetext{
${ }^{9}$ Since Column (A) in Appendix Table 3 includes public health spending only in the regression, the coefficient of health spending may pick up the residual effects of other categories of spending as well. The results from Columns (3) and (A), however, are very similar. Including government saving as an additional explanatory variable in Column (A) also does not have a significant effect on the results (not reported).

${ }^{10}$ We obtain very similar results for public health and social security spending, regardless of whether all three items are simultaneously included (Column 3 ) or each spending category is estimated separately (Columns A and $\mathrm{C}$ in Appendix Table 3). As Column (B) shows, therefore, it seems reasonable to view public education spending as having a significant, independent negative effect on saving. Nonetheless, the result on public spending on education should be interpreted with caution.
} 


\section{Assessing Impact of EXPanding Social Programs in China: Methodology AND DATA}

This and the next section estimate the potential household consumption impact of higher social expenditures in China using a generational accounting framework and building on the findings above. ${ }^{11}$ According to this framework, there are three channels through which an increase in government social expenditures can raise household consumption (see Box 2).

First, social expenditures will increase the aggregate level of household lifetime resources and, hence, current consumption. This is because when households make decisions regarding the level of current consumption, they are assumed to factor in not only current income but also the expected future stream of income. An expansion of government social expenditures to cover a greater share of expenditures currently borne by households (e.g., through lower health and education charges or higher pensions) will, therefore, increase household lifetime resources and household current consumption. Even households not currently incurring such expenditures (or receiving such transfers) can be expected to increase current consumption since they expect to incur such costs (or receive such benefits) in the future. ${ }^{12}$ The consumption impact of increasing social expenditures will, of course, be higher if this is financed by running down the budget surplus compared to tax financing.

Second, these impacts will increase further to the extent that these expenditures are concentrated in households with relatively high average propensities to consume out of lifetime income. For example, pension transfers to the elderly can be expected to have a higher consumption impact than transfers to younger age groups, since the elderly tend to have a relatively high propensity to consume out of remaining lifetime income. This holds more generally for social expenditures that are positively correlated with age, such as health expenditures.

Third, social expenditures can generate an additional impact on current consumption through decreasing precautionary savings. Higher social expenditures mean that households are faced with the possibility of lower future health and education costs and higher retirement incomes and, therefore, may save less to cover these expenses.

The first two channels capture the "income effect" of higher social expenditures, and can be estimated by applying the generational accounting framework to household-level

\footnotetext{
${ }^{11}$ This approach is based on the analysis in Gokhale, Kotlikoff, and Sabelhaus (1997). See also Kirsanova and Sefton (2007) for a very similar approach.

${ }^{12}$ Note that a "temporary" or one-off increase in expenditures (e.g., as part of a stimulus package) can be expected to have a much smaller impact on current consumption, since households will distribute the associated increase in real income over their life cycle.
} 
data. The third channel represents the "insurance effect" of these expenditures; the magnitude of this impact is more difficult to identify and needs to be assessed separately using alternative estimation techniques. Below, the potential insurance effect is inferred from a study for Taiwan and results from the above panel regressions and should, therefore, be interpreted as illustrative of the potential magnitude of this effect. Both the income and insurance effects are then combined to gauge the overall savings impact.

\section{Box 2. Methodology for Estimating Consumption Impact of Social Expenditures}

A standard decomposition formula is used to capture various channels through which an increase in social expenditures can boost current household consumption. The starting point for the decomposition formula is a consumption function defined over relevant socioeconomic groups (e.g., young/old, urban/rural, poor/non-poor). For each group, $i$, the level of consumption in time $t\left(c_{i t}\right)$ is defined as:

$$
c_{i t}=\alpha_{i} r_{i t}
$$

where $\alpha_{i}$ is the average propensity to consume today of each group out of lifetime resources ${ }^{l}$ and $r_{i t}$ is the net present value of the group's remaining lifetime resources (i.e., of net lifetime disposable income). This approach is consistent with a basic life-cycle model where households base current consumption decisions on lifetime resources and reallocate changes in resources at any point in their lifetime across years. Total consumption can then be decomposed as follows:

$$
c_{t}=\left(\sum_{i} \alpha_{i} \frac{r_{i t}}{r_{t}} \frac{P_{i t}}{P_{t}}\right) P_{t} r_{t}
$$

where $P_{i t}$ is the number of individuals in the group and $r_{t}=\sum_{i}\left(P_{i t} / P_{i}\right) r_{i t}$ is the average level of lifetime resources in the population.

Based on this equation, changes in consumption can be decomposed into changes in each of these four components of total consumption. These changes can be interpreted as follows:

- Changes in total lifetime household income, $P_{t} r_{t}$;

- Changes in the distribution of total lifetime household income across groups, $\frac{r_{i t}}{r_{t}}$;

- $\quad$ Changes in group propensities to consume out of group lifetime income, $\alpha_{i}$;

- $\quad$ Changes in the distribution of the population across groups, $\frac{P_{i t}}{P_{t}}$.

The first two channels together constitute the "income effect" (reflecting the increase in household real incomes) and the third captures the "insurance effect" (reflecting the decrease in precautionary savings). Whereas the income effect can be estimated by applying generational accounting to household survey data (see Box 3), the insurance effect needs to be estimated using alternative microeconometric techniques. In the current version of the paper, the final "demographic effect" is kept fixed, but it is straightforward to impose projected demographic trends onto the household survey data to project the likely impact of demographic change on the average propensity to consume and thus on total consumption.

${ }^{1}$ Note that the average propensity to consume out of lifetime resources will be substantially lower than the consumption rate (i.e., consumption out of current income), since lifetime income is distributed across future years. Consistent with this, the average propensity to consume will be higher for the elderly compared to the young. 
Implementing the above framework entails three steps. These are (i) the calculation of lifetime resources for various socio-economic groups; (ii) the estimation of their average propensities to consume; and (iii) the translation of increases in public expenditures into changes in lifetime resources. Individuals are first allocated to groups according to three characteristics: their current income (based on income quintiles), residence in urban or rural areas, and age:

- $\quad$ Calculating lifetime (disposable) resources requires data on individual wealth, incomes, taxes, and transfers. These data are taken from household budget survey data. Each individual is allocated to a specific group and then assigned the group mean for each of these lifetime income components. Lifetime resources for each group member can be estimated based on group averages and the assumption that future flows for each group member are given by the group averages for successive age groups. For example, one can assume that next year's income for a rural individual currently aged 20 and in the bottom consumption quintile is the current income for the same type individual aged 21 years. ${ }^{13}$ In other words, the growth rate of incomes for a group member is given by the growth in average incomes with age for that group. Net present values are then calculated by assuming a common discount rate. See Box 3 for a more detailed discussion of the household data used in the analysis.

- $\quad$ The group average propensities to consume out of lifetime income are then calculated as the ratio of current consumption to lifetime income. Figure 3 presents the pattern of these propensities across age, urban/rural, and income groups. As expected, they increase with age and are also higher for rural and lower-income groups. The relative importance of the age effect is clear and reflects the simple fact that remaining lifetime incomes of the elderly are allocated over fewer years.

- $\quad$ Expenditure reforms involve increasing the flow of resources to the different groups over time. A given expenditure reform is translated into an additional flow of resources to each group over time and the impact on current consumption is derived as the increase in each group's net present value of lifetime resources times their average propensity to consume. For example, increases in public health expenditures associated with reduced health care charges can be expected to lead to a larger proportional increase in the net present value of lifetime resources for the elderly (who have larger expenditures today) compared with the increase for the young (who incur these large expenses in the future). Appendix Table 4 presents the consumption shares of various consumption categories across income groups.

\footnotetext{
${ }^{13}$ A more rigorous approach would also take into account the existence of cohort and time effects based on repeated cross-sections of household data. Such an analysis is undertaken by Chamon and Prasad (2008), who also show that the results are qualitatively very similar.
} 


\section{Box 3. Constructing Lifetime Income and Average Propensities to Consume}

The data for the analysis are taken from the Chinese Household Income Survey (CHIP). The survey questionnaire is designed by the Institute of Economics of the Chinese Academy of Social Sciences and interviews implemented by the National Bureau of Statistics (NBS). The sample is a sub-sample of the one used by the NBS for its own nationally representative annual survey, which is not publicly available. CHIP covers households in 12 urban provinces (6,800 households and 20,600 individuals) and 22 rural (9,200 households and 38,000 individuals) as well as migrant households in the 12 urban provinces $(2,000$ households and 5,300 individuals). The data are for 2002, the latest survey available.

The CHIP contains information on assets, incomes, and consumption. All consumption data are at the household level so that individual per capita consumption levels are calculated as total household consumption divided by total household size. The urban sector survey provides income data at the individual level so that incomes can be attributed to individuals. The rural sector survey provides nonagricultural income at the individual level and agricultural income at the household level. Therefore, individual income levels are calculated as individual non-agricultural income plus the per capita agricultural income calculated as total household agricultural income divided by household size. Per capita net asset levels are calculated as the value of net household assets, including the market value of privately-owned houses, divided by the household size.

The aggregated survey income and consumption data for socioeconomic groups are merged with macroeconomic national data and demographic data. The CHIP is used to calculate the distribution of average propensities to consume across different age and income groups in both the urban and rural sectors. Individuals between 18 and 73 years old (the life expectancy in China) are allocated to age groups, and the net present value of individual income is calculated by assuming future wages follow that of age-specific wages augmented by a growth rate of 7.7 percent and discounted based on an interest rate of 11.7 percent and on survival rates taken from the latest 2006 WHO Life Table for China, giving a discount rate of 0.96 . The calculation of lifetime resources also includes the present value of net transfers, net pension benefits, in-kind benefits for education and health, and financial assets. The average propensity to consume is calculated as the current consumption level including education and health spending divided by lifetime resources. These propensities are then applied to 2007 national accounts and population data (the latest available) to calculate group consumption levels.

Although the use of $\mathbf{2 0 0 2}$ household survey data primarily reflects data availability constraints, these data are still likely to provide a good approximation of the consumption impact of expanded social expenditure programs. According to the summary of household survey data presented in Chamon and Prasad (2008), the household savings rate increased from 16.7 percent in 1992 to 24.7 percent in 2006, with most of this increase occurring by 2002 when the savings rate reached 23.1 percent. Similarly, most of the increase in household expenditures on health and education had occurred before 2002. The share of health expenditures in total consumption increased from 2.5 percent in 1992 to 7.4 percent in 2004 , compared to 7.1 percent in 2002 . The share of education expenditures increased from 8.8 to 14.4 percent over the same period, compared to 15 percent in 2002. In addition, the Chamon and Prasad (2008) study is restricted to urban households, while the CHIP also covers rural households. 
Figure 3. Average Propensities to Consume Out of Lifetime Income
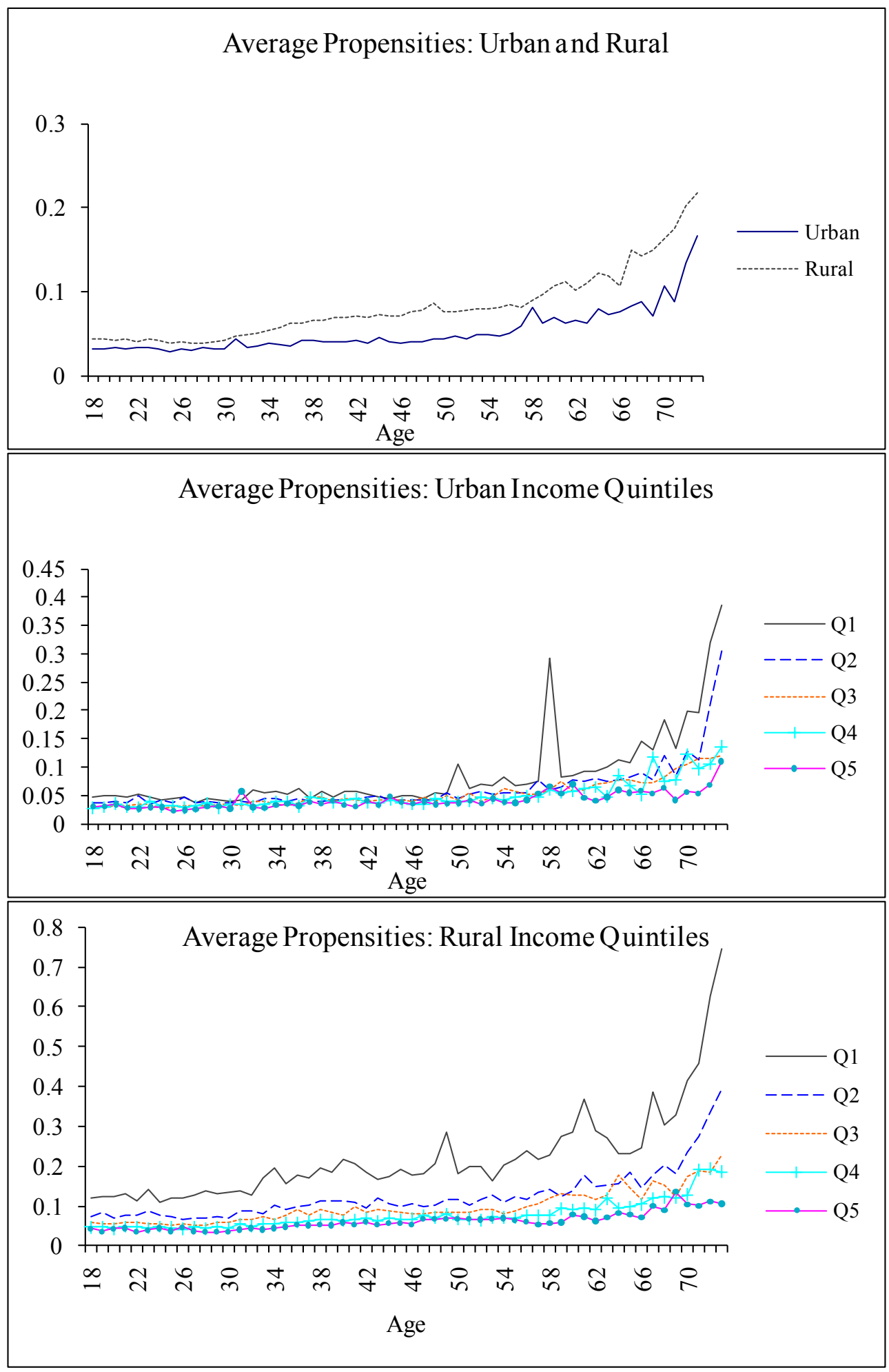

Source: Staff estimates based on 2002 CHIP household survey data.

Note: Q1 represents the quintile with the lowest income, and Q5 the quintile with the highest income. 
The implicit assumption that changes in household consumption depend on changes in household lifetime incomes means that the estimated income effects should be viewed as upper bounds. For example, credit-constrained households will be unable to increase current consumption in line with higher lifetime incomes, thus reducing the consumption impact of higher social expenditures. Chamon and Prasad (2008) found that, contrary to what would be expected from the life-cycle theory in the absence of credit constraints, both young and old households have higher savings rates compared to other households. This is attributed to the inability of young households to borrow to finance future lumpy consumption (e.g., purchasing a house or consumer durable, or saving to finance future education costs for children) and to high precautionary savings by the elderly due to the risk of incurring high health costs in the future. Of course, the expenditure reforms themselves may help to reduce these savings rates for the young and elderly. However, to the extent that credit constraints persist, realization of these upper-bound consumption impacts will be dependent on the introduction of supporting financial sector reforms.

\section{ASSESSING THE IMPACT OF EXPENDITURE REFORMS}

Assessing the impact of social expenditure reforms on household consumption requires the identification of specific expenditure measures and the outlays on them. This section assesses the consumption impact of an increase in public expenditures on pensions, health care, and education. These reform measures have been discussed by the government as part of their recent reform proposals, and identified in the literature as important in reducing the high household savings rate. The consumption impact of such reforms is explored by simulating the following reforms within the generational accounting framework described above:

- Pension transfer: A cash transfer proportional to current income is given to all individuals over 55 years old (i.e., universal coverage). Each individual starts to receive this transfer after reaching this age threshold. According to McKinsey (2009), in 2009 pension coverage is currently extended to around 90 percent of urban households and 20-25 percent of rural households and migrants. The reform therefore should be interpreted as significantly expanding coverage, including in the rural areas. Disaggregating the simulated reform by urban and rural areas enables the identification of the impact of a reform that extends pension coverage to rural areas. ${ }^{14}$

- Education transfer: A transfer proportional to current education expenditures is given to all individuals. The time profile of this transfer mirrors the age profile of education expenditures. For example, this year 20-year-old individuals receive a transfer proportional to their current share of total education expenditures, and next year they

\footnotetext{
${ }^{14}$ McKinsey (2009) estimated the impact of a fully funded scheme.
} 
receive the transfer of a current 21-year-old. The amount received will depend on the size of the budget allocation of the government. ${ }^{15}$

- Health transfer: A transfer proportional to current health expenditures is given to all individuals. As for education, the time profile of this transfer mirrors the age profile of education expenditures. McKinsey (2009) also evaluated the impact of increasing public health spending.

Appendix Tables 5 and 6 presents the average transfer received by different age and income groups under the different expenditure reforms.

The expenditure reforms simulated below are assumed to be permanent. This is so both in terms of their continued existence over the lifetime of each group and their financing through a permanent decrease in the fiscal surplus. The budget for these reforms is assumed fixed at 1 percent of GDP each year so that the absolute size of the budgetary allocation for these expenditures increases with GDP. These are financed from existing budgetary surpluses - i.e., they are not assumed to entail an increase in taxes.

The financing of expenditures by reducing the fiscal surplus results in an increase in total household net lifetime resources. The net consumption impact reflects the transfer of resources from government savings to households, with the increase in household incomes in turn leading to an increase in current household consumption. If expenditure reforms were budget neutral (e.g., financed from income taxes), then the net consumption impact would obviously be much smaller and reflect simply a redistribution of resources across households with different average propensities to consume as well as some impact via the insurance channel. Similarly, temporary reforms (akin to "stimulus packages") would have substantially lower impacts on current consumption since the change in lifetime resources would be much smaller.

As indicated earlier, expenditure reforms will have both an "income effect" and an "insurance effect" on current consumption. The income effect reflects the increase in lifetime resources, with education and health transfers reducing the net cost of these services to households. The insurance effect reflects the increase in the average propensity to consume out of lifetime resources due to a decrease in precautionary savings.

\section{Income effect}

The variation in income effects reflect the age-profile of expenditures. Table 3 presents the income effect for the three types of government social expenditures under Simulation 1,

\footnotetext{
${ }^{15}$ McKinsey (2009) evaluated the impact of an expansion of student loans for tertiary education but not the consumption impact of higher public education expenditures.
} 
disaggregating by urban and rural population. Since the lifetime budget for the latter is smaller, so too will be the consumption impacts. The results suggest that the impact on current consumption is highest for pension expenditures (at 1.4 percent of GDP), followed by health ( 0.8 percent of GDP), and education ( 0.5 percent of GDP). ${ }^{16}$

\section{The impact of a unit of government social spending on consumption is substantially} higher in rural areas. This reflects the higher propensities to consume in rural areas, which in turn partly reflects lower income levels. For example, under Simulation 1 the impact of pension expenditures in urban areas is 0.9 compared to 0.5 in rural areas. However, only 25 percent of expenditures go to rural households. Adjusting for the difference in pension expenditures, the income effect of pension expenditures in rural areas is about 67 percent higher than that for urban areas-i.e., $(0.5 / 0.25)$ divided by $(0.9 / 0.75)$. The equivalent differences for health and education are 56 percent and 55 percent respectively. Targeting expenditures to rural areas will clearly result in a higher impact on household consumption. Similarly, targeting transfers to low income households is likely to be a more cost-effective approach to increasing household consumption.

\section{Table 3. Income Impact of Expenditure Reforms on Household Consumption} (In percent of GDP)

\begin{tabular}{r|c|c|c}
\hline $\begin{array}{c}\text { Expenditure } \\
\text { Reform }\end{array}$ & Pension & Health & Education \\
\hline Simulation & & & \\
Total & 1.42 & 0.77 & 0.51 \\
Urban & 0.92 & 0.46 & 0.24 \\
Rural & 0.50 & 0.32 & 0.27 \\
\hline Budget Shares & & & \\
Urban & 0.75 & 0.69 & 0.58 \\
Rural & 0.25 & 0.31 & 0.42 \\
\hline
\end{tabular}

Note: Simulations assume a 1 percent of GDP increase in each expenditure category annually. Source: Staff estimates based on CHIP 2002 household survey data.

\section{Insurance effect}

The insurance effect is more difficult to assess given the paucity of empirical evidence on the determinants of precautionary savings. One relevant study is as noted earlier by Chou, Liu, and Hammitt (2006), which analyzed the impact of the extension of Taiwan's health insurance coverage (from 57 percent of the population in 1994 to 96 percent in 2000) on household precautionary savings. Their estimates suggest that an increase in health

\footnotetext{
${ }^{16}$ Under the smaller lifetime budget in Simulation 2, the income effects are lower at 0.8 percent for pensions, 0.5 percent for health, and 0.4 percent for education. Improved targeting could increase these further-for example, if pensions were only given to those without pensions (e.g., by increasing coverage). Since the beneficiaries under this scenario are more likely to be rural, poorer than existing pension beneficiaries, and therefore have higher average propensities to consume, the impact on current consumption would be larger.
} 
expenditures of 1 percentage point of GDP increased current household consumption by 0.4 to 0.6 percent of GDP due to the insurance effect. To estimate the equivalent insurance impacts of education and pension expenditures for this paper, we take the ratio of this health insurance impact to the total (income and insurance) health impact estimated in Section III. This gives a ratio of 0.24 , i.e. 0.5 divided by 2.1 . Applying this ratio to the estimated total consumption impact of education and pension expenditures (estimated at 1.3 and 0.7 , respectively) gives insurance impacts of 0.31 and 0.17 percent of GDP, respectively.

\section{Total effect}

\section{Adding the income and insurance effects suggests that the household consumption} impact of social expenditures may be substantial. Table 4 presents the total household consumption impact across expenditures, calculated by adding the income effects from Table 3 to the insurance impacts identified above. The resulting total consumption impacts range from 1.6 percent of GDP for pensions, ${ }^{17} 1.3$ percent for health, ${ }^{18}$ and 0.8 percent for education. ${ }^{19}$ This implies that a 1 percentage point of GDP increase in social expenditures allocated evenly across these expenditure categories would result in a permanent increase in household consumption of 1.2 percent of GDP. Allocating a higher share of expenditures to health and pension expenditures can be expected to generate a higher household consumption impact.

\begin{tabular}{|c|c|c|c|}
\hline Expenditure Reform & Pension & Health & Education \\
\hline Total & 1.6 & 1.3 & 0.8 \\
\hline Income Effect & 1.4 & 0.8 & 0.5 \\
\hline Insurance Effect & 0.2 & 0.5 & 0.3 \\
\hline
\end{tabular}

Note: Income effects assume a 1 percent of GDP increase in each expenditure category annually. Source: Staff estimates.

\footnotetext{
${ }^{17}$ McKinsey (2009) estimated that the consumption impact of a fully funded PAYG pension scheme would range from -0.2 to 0.5 percent of GDP. Our estimates of such a scheme suggest that financing through income taxation would decrease our estimated consumption impact by 0.57 percent of GDP, giving a net impact of around 1.1 percent.

${ }^{18}$ The health impact is substantially higher than that reported in McKinsey (2009). That report estimates that household consumption can increase by 0.4 to 0.6 percent of GDP through a combination of increasing government health expenditure by 1.1 to 2.8 percent of GDP and expanding health insurance coverage (presumably self-financed). This suggests that a 1 percent increase in public health expenditures would increase consumption by around 0.25 percent of GDP.

${ }^{19}$ McKinsey (2009) estimated that the consumption impact of increasing access to student loans from the current 10 percent to between 33 and 50 percent would range from 0.4 to 0.7 percentage points of GDP.
} 
The results suggest that increasing government social expenditures can make an important contribution to increasing household consumption. For example, assuming government expenditures are evenly distributed across education, health, and pension expenditures, a 3 percent of GDP increase in the household consumption ratio would require a 2.5 percent of GDP increase in total social expenditures maintained over the medium term. Targeting a higher proportion of the expenditure increase to health and pensions or to rural and low-income households would reduce the required budget increase. For example, the same 3 percentage point of GDP increase in the household consumption ratio would require only an increase of 1.9 percent increase in pension expenditures or, alternatively, a 2.2 percent increase in health expenditures. These reforms could be complemented by structural reforms that increase the share of wages in national income by rebalancing domestic growth towards domestic consumption. For example, simulating a 1 percent additional growth in labor income in China within the above framework generates a 0.7 percent increase in current household consumption.

These consumption impacts would obviously be lower if the increase in social expenditures was tax financed. If the 1 percent of GDP increase in expenditures in each expenditure category is financed by an increase in income taxes, this would lead to an offsetting decrease in consumption of nearly 0.6 percent of GDP. This would imply a net increase in household consumption limited to 0.2 percent of GDP for education, 0.7 percent for health, or 1.0 percent for pensions - much smaller than in the case of a reduction in the fiscal surplus. The positive net impact reflects the redistributive effect of the combined tax and expenditure reforms, with resources being redirected from those with low to those with high propensities to consume.

\section{Summary and Policy Implications}

This paper has explored a number of issues related to the low and declining household consumption ratio in China. It first examined the proximate causes that have been advanced to explain the developments in this ratio, including the marked increase in the household savings rate and the decline in the share of household income in GDP. An underlying cause of the higher savings rate is apparently the greater uncertainty facing the household sector following structural changes in the economy, and the reduced provision of support for education, health, and old age pensions by the government. The paper then undertook an analysis of the determinants of the household savings rate in a panel of advanced and emerging market countries. The results support the premise that government social expenditures (on education, health, and pensions) can be important determinants of the household savings rate.

Based on the above analyses, simulation analyses were used to explore how and through what channels an increase in government social expenditures in China could lead to an increase in the consumption ratio. Three channels were identified: (i) a direct income channel; (ii) a distributional channel; and (iii) an "insurance" channel. Simulations using 
household survey data show that the effect of an increase in public spending on the three categories could be significant: in particular, a sustained one percentage point of GDP increase in government spending is likely to lead to an increase in the household consumption ratio of up to $1 \frac{1}{4}$ percentage points of GDP.

These results also underline the likelihood of broader benefits of expenditure reforms regarding China's large external current account surplus and global imbalances. The adjustment required to reduce the current account balance to a more sustainable level is large. Estimates suggest that household consumption would have to increase by some 3 to 4 percentage points of GDP, assuming the corporate sector and government savings rate remains unchanged, to help rebalance world demand. This would suggest that other structural reforms relating for instance to the availability of credit, retail distribution, measures to increase the share of wages in national income by rebalancing domestic growth towards domestic consumption, etc., would also be important. Nonetheless, the findings of this paper suggest that a greater provision of public expenditure on health, education, and pensions could make an important contribution. 


\section{Appendix Table 3. Individual Component of Public Expenditures}

Household Saving Panel Regression, 1990-2008 for OECD Sample

Dependent variable: Household Saving (Percent of household disposable income)

\begin{tabular}{|c|c|c|c|}
\hline Explanatory Variables & $\begin{array}{l}\text { (A) } \\
\text { FE }\end{array}$ & $\begin{array}{l}\text { (B) } \\
\text { FE }\end{array}$ & $\begin{array}{l}\text { (C) } \\
\text { FE }\end{array}$ \\
\hline Growth, per capita GDP & $\begin{array}{c}-0.06 \\
(-0.28)\end{array}$ & $\begin{array}{c}-0.11 \\
(-0.55)\end{array}$ & $\begin{array}{l}-0.42^{* *} \\
(-2.09)\end{array}$ \\
\hline Initial GDP per capita (log) & $\begin{array}{c}207.9^{* * *} \\
(3.24)\end{array}$ & $\begin{array}{l}98.73 \\
(1.45)\end{array}$ & $\begin{array}{l}41.36 \\
(0.48)\end{array}$ \\
\hline Initial GDP per capita (log), squared & $\begin{array}{c}-10.01^{* * *} \\
(-3.12)\end{array}$ & $\begin{array}{c}-4.83 \\
(-1.43)\end{array}$ & $\begin{array}{c}-2.55 \\
(-0.61)\end{array}$ \\
\hline Private credits & $\begin{array}{c}-1.92 \\
(-1.69)\end{array}$ & $\begin{array}{c}-2.24 \\
(-1.60)\end{array}$ & $\begin{array}{c}-0.97 \\
(-1.10)\end{array}$ \\
\hline Old-age dependency ratio & $\begin{array}{l}-0.61^{* *} \\
(-2.22)\end{array}$ & $\begin{array}{c}-0.92^{\star * *} \\
(-3.02)\end{array}$ & $\begin{array}{c}-0.79^{* * *} \\
(-3.05)\end{array}$ \\
\hline Young-age dependency ratio & $\begin{array}{l}0.46^{* *} \\
(2.68)\end{array}$ & $\begin{array}{c}0.40^{*} \\
(1.75)\end{array}$ & $\begin{array}{l}-0.19 \\
(0.67)\end{array}$ \\
\hline Public health spending & $\begin{array}{c}-6.74^{* * *} \\
(-4.92)\end{array}$ & & \\
\hline Public health spending, squared & $\begin{array}{c}0.42^{* * *} \\
(5.09)\end{array}$ & & \\
\hline Public education spending & & $\begin{array}{r}-5.76^{\star * *} \\
(-3.43)\end{array}$ & \\
\hline Public education spending, squared & & $\begin{array}{c}0.37^{* * *} \\
(3.23)\end{array}$ & \\
\hline Social security spending & & & $\begin{array}{l}-2.31^{\text {** }} \\
(-2.59)\end{array}$ \\
\hline Social security spending, squared & & & $\begin{array}{l}0.06^{* *} \\
(2.57)\end{array}$ \\
\hline No. of Obs. & 78 & 78 & 78 \\
\hline No. of countries & 24 & 24 & 24 \\
\hline $\mathrm{R}^{\wedge} 2$ & 0.78 & 0.72 & 0.71 \\
\hline
\end{tabular}

Note: The panel consists of four 5-year periods for 24 countries. Heteroskedasticity and country-specific autocorrelation consistent t-statistics are reported in parentheses. Levels of significance are indicated by asterisks: ${ }^{* * *} 1$ percent, ${ }^{* *} 5$ percent, ${ }^{*} 10$ percent. An intercept term is included in each regression.

\section{Appendix Table 4. Consumption Shares of Various Consumption Categories}

\begin{tabular}{|c|c|c|c|c|c|c|c|c|c|c|}
\hline $\begin{array}{l}\text { Income } \\
\text { Quintiles }\end{array}$ & Food & $\begin{array}{l}\text { Non- } \\
\text { food }\end{array}$ & $\begin{array}{r}\text { Urban } \\
\text { Housing }\end{array}$ & Education & Health & Food & $\begin{array}{l}\text { Non- } \\
\text { food }\end{array}$ & $\begin{array}{r}\text { Rural } \\
\text { Housing }\end{array}$ & Education & Health \\
\hline Q1 & 0.405 & 0.274 & 0.175 & 0.071 & 0.075 & 0.465 & 0.242 & 0.145 & 0.091 & 0.057 \\
\hline Q2 & 0.387 & 0.309 & 0.153 & 0.078 & 0.073 & 0.468 & 0.266 & 0.125 & 0.088 & 0.053 \\
\hline Q3 & 0.371 & 0.334 & 0.150 & 0.077 & 0.068 & 0.443 & 0.285 & 0.160 & 0.069 & 0.043 \\
\hline Q4 & 0.346 & 0.343 & 0.180 & 0.071 & 0.059 & 0.417 & 0.292 & 0.165 & 0.080 & 0.046 \\
\hline Q5 & 0.311 & 0.371 & 0.186 & 0.075 & 0.057 & 0.348 & 0.323 & 0.205 & 0.088 & 0.036 \\
\hline Average & 0.364 & 0.326 & 0.169 & 0.074 & 0.066 & 0.428 & 0.282 & 0.160 & 0.083 & 0.047 \\
\hline
\end{tabular}

Source: Staff estimates based on 2002 CHIP household survey data. 
Appendix Table 5. Per Capita Transfers under Different Social Expenditure Reforms

\begin{tabular}{|c|c|c|c|c|c|c|c|c|}
\hline \multirow[t]{2}{*}{ Age } & \multicolumn{4}{|c|}{ Urban } & \multicolumn{4}{|c|}{ Rural } \\
\hline & Assets & Income & Education & Health & Assets & Income & Education & Health \\
\hline 18 & 39743 & 372 & 290 & 27 & 8325 & 1402 & 334 & 31 \\
\hline 19 & 43187 & 414 & 354 & 29 & 7873 & 1260 & 336 & 39 \\
\hline 20 & 37324 & 649 & 337 & 30 & 8072 & 1181 & 243 & 33 \\
\hline 21 & 44410 & 1397 & 261 & 35 & 8204 & 1290 & 226 & 37 \\
\hline 22 & 39042 & 1690 & 214 & 34 & 7805 & 1386 & 160 & 39 \\
\hline 23 & 45992 & 2889 & 111 & 41 & 7704 & 1343 & 116 & 40 \\
\hline 24 & 47072 & 3387 & 78 & 44 & 8286 & 1349 & 80 & 43 \\
\hline 25 & 56797 & 4625 & 75 & 37 & 7641 & 1421 & 89 & 42 \\
\hline 26 & 40406 & 4861 & 75 & 35 & 7472 & 1270 & 50 & 37 \\
\hline 27 & 43441 & 4880 & 58 & 36 & 8197 & 1363 & 41 & 40 \\
\hline 28 & 39415 & 5699 & 96 & 41 & 8443 & 1564 & 45 & 37 \\
\hline 29 & 39922 & 6542 & 106 & 43 & 8514 & 1626 & 54 & 35 \\
\hline 30 & 38313 & 7628 & 148 & 33 & 9136 & 1904 & 67 & 31 \\
\hline 31 & 46182 & 8377 & 187 & 34 & 10258 & 1809 & 83 & 49 \\
\hline 32 & 37348 & 7515 & 184 & 57 & 10607 & 1930 & 124 & 32 \\
\hline 33 & 39333 & 9284 & 202 & 35 & 9954 & 1909 & 141 & 27 \\
\hline 34 & 52636 & 9774 & 252 & 48 & 11502 & 1998 & 200 & 34 \\
\hline 35 & 47233 & 9481 & 235 & 39 & 11411 & 2296 & 196 & 33 \\
\hline 36 & 38349 & 9284 & 199 & 35 & 10684 & 2266 & 278 & 37 \\
\hline 37 & 50309 & 9926 & 318 & 36 & 12687 & 2325 & 312 & 26 \\
\hline 38 & 51734 & 9560 & 268 & 36 & 12007 & 2267 & 345 & 26 \\
\hline 39 & 49219 & 9762 & 305 & 32 & 13176 & 2461 & 424 & 26 \\
\hline 40 & 63633 & 10169 & 327 & 38 & 12018 & 2050 & 481 & 35 \\
\hline 41 & 55964 & 9661 & 310 & 41 & 12880 & 2413 & 432 & 49 \\
\hline 42 & 53693 & 9706 & 341 & 41 & 12390 & 2435 & 391 & 34 \\
\hline 43 & 62401 & 10527 & 393 & 38 & 12629 & 2227 & 423 & 34 \\
\hline 44 & 51913 & 9210 & 382 & 35 & 11584 & 1490 & 402 & 42 \\
\hline 45 & 47947 & 9603 & 345 & 37 & 9810 & 1593 & 333 & 32 \\
\hline 46 & 49309 & 9471 & 335 & 29 & 9627 & 1502 & 291 & 45 \\
\hline 47 & 47387 & 8839 & 334 & 34 & 9511 & 1458 & 268 & 38 \\
\hline 48 & 50545 & 9026 & 287 & 34 & 9987 & 1419 & 281 & 56 \\
\hline 49 & 49896 & 9472 & 230 & 33 & 8754 & 1565 & 222 & 49 \\
\hline 50 & 43669 & 8854 & 182 & 36 & 9595 & 1400 & 178 & 41 \\
\hline 51 & 52642 & 9006 & 163 & 41 & 9838 & 1245 & 131 & 37 \\
\hline 52 & 54751 & 8932 & 162 & 46 & 9809 & 1174 & 168 & 45 \\
\hline 53 & 51701 & 8571 & 112 & 47 & 10505 & 1250 & 95 & 66 \\
\hline 54 & 45751 & 8614 & 92 & 50 & 9739 & 1428 & 111 & 53 \\
\hline 55 & 55705 & 9218 & 105 & 48 & 9074 & 1459 & 87 & 54 \\
\hline 56 & 52896 & 8318 & 93 & 78 & 8470 & 1352 & 59 & 103 \\
\hline 57 & 61208 & 8739 & 60 & 88 & 10698 & 1357 & 57 & 81 \\
\hline 58 & 52418 & 8040 & 69 & 94 & 8833 & 1095 & 56 & 88 \\
\hline 59 & 51825 & 8893 & 171 & 86 & 10332 & 1218 & 44 & 89 \\
\hline 60 & 48368 & 8062 & 82 & 87 & 8892 & 1112 & 103 & 132 \\
\hline 61 & 42882 & 7475 & 67 & 88 & 9993 & 1086 & 70 & 86 \\
\hline 62 & 41134 & 7427 & 70 & 99 & 8537 & 1075 & 53 & 96 \\
\hline 63 & 49095 & 6765 & 66 & 99 & 9895 & 1038 & 70 & 75 \\
\hline 64 & 48824 & 7982 & 91 & 89 & 8753 & 1120 & 78 & 92 \\
\hline 65 & 45892 & 6948 & 53 & 95 & 8504 & 883 & 84 & 84 \\
\hline 66 & 38477 & 5623 & 80 & 78 & 9559 & 1217 & 91 & 65 \\
\hline 67 & 52930 & 6996 & 95 & 103 & 7219 & 1054 & 130 & 86 \\
\hline 68 & 48985 & 7275 & 96 & 86 & 7160 & 1160 & 91 & 85 \\
\hline 69 & 53534 & 7012 & 128 & 86 & 6971 & 1180 & 74 & 54 \\
\hline 70 & 40391 & 8487 & 70 & 100 & 7600 & 723 & 120 & 98 \\
\hline 71 & 53443 & 6319 & 63 & 73 & 9373 & 1181 & 150 & 89 \\
\hline 72 & 40568 & 6870 & 88 & 113 & 7737 & 1101 & 204 & 71 \\
\hline 73 & 41888 & 7657 & 120 & 100 & 8046 & 1035 & 137 & 90 \\
\hline Average & 47662 & 7353 & 179 & 55 & 9505 & 1495 & 177 & 54 \\
\hline
\end{tabular}

Source: Staff calculations. 


\section{Appendix Table 6. Per Capita Transfers and Consumption}

\begin{tabular}{|c|c|c|c|c|}
\hline Income Quintile & Consumption & Pension & Health & Education \\
\hline $\begin{array}{l}\text { Q1 } \\
\text { Q2 } \\
\text { Q3 } \\
\text { Q4 } \\
\text { Q5 }\end{array}$ & $\begin{array}{l}11284 \\
12594 \\
14537 \\
18148 \\
26942 \\
\end{array}$ & $\begin{array}{l}244 \\
325 \\
425 \\
539 \\
783 \\
\end{array}$ & $\begin{array}{l}386 \\
423 \\
449 \\
490 \\
703\end{array}$ & $\begin{array}{l}286 \\
349 \\
399 \\
457 \\
722\end{array}$ \\
\hline $\begin{array}{l}\text { Q1 } \\
\text { Q2 } \\
\text { Q3 } \\
\text { Q4 } \\
\text { Q5 }\end{array}$ & $\begin{array}{l}3668 \\
3991 \\
4543 \\
5370 \\
8472\end{array}$ & $\begin{array}{c}13 \\
32 \\
52 \\
84 \\
147\end{array}$ & $\begin{array}{l}47 \\
48 \\
44 \\
55 \\
69\end{array}$ & $\begin{array}{c}58 \\
62 \\
55 \\
75 \\
131 \\
\end{array}$ \\
\hline
\end{tabular}

Source: Staff estimates based on 2002 CHIP household survey data. 


\section{References}

Barnett, S., and R. Brooks, 2010, "China: Does Government Health and Education Spending Boost Consumption?” IMF Working Paper No. 10/16.

Barrell, R., I. Hurst, and S. Kirby, 2009, "How to Pay for the Crisis or Macroeconomic Implications of Pension Reform," NIESR Discussion Paper No. 333.

Beck, Thorsten, Asli Demirgüç-Kunt, and Ross Levine, 2000, “A New Database on Financial Development and Structure,” World Bank Economic Review, 14, pp. 597-605, 2007 update.

Bosworth, B., and G. Chodorow-Reich, 2007, "Saving and Demographic Change: The Global Dimension," Working Paper, Center for Retirement Research at Boston College.

Caballero, R. J., E. Farhi, and P. Gourinchas, 2008, “An Equilibrium Model of 'Global Imbalances' and Low Interest Rate," American Economic Review 98: pp. 358-93.

Chamon, M., and E. Prasad, 2008, "Why are Saving Rates of Urban Households in China Rising?” Brookings Global Working Paper No. 27.

Chou, S., J. Liu, and J. K. Hammitt, 2006, "Households' Precautionary Behaviors-the Effects of the Introduction of National Health Insurance in Taiwan," Review of Economics of the Household 4: pp. 395-421.

Edwards, S., 1996, "Why are Latin America's Saving Rates so Low? An International Comparative Analysis,” Journal of Development Economics Vol. 51(1): pp. 5-44.

Gokhale J., L. J. Kotlikoff, and J. Sabelhaus, 1996, "Understanding the Postwar Decline in U.S. Saving: A Cohort Analysis," Brookings Papers on Economic Activity, No. 1, pp. 315-90.

Gruber, J., and A. Yelowitz, 1999, Public Health Insurance and Private Savings 107(6): pp. 1249-74.

Heston, A., R. Summers, and B. Aten, 2009, Penn World Table Version 6.3. Center for International Comparisons of Production, Income and Prices at the University of Pennsylvania.

Horioka C., and J. Wan, 2006, "The Determinants of Household Saving in China: A Dynamic Panel Analysis of Provincial Data,” NBER Working Paper, No. 12723. 
International Monetary Fund, 2005, World Economic Outlook, A Survey by the Staff of the International Monetary Fund, World Economic and Financial Surveys (Washington).

Kantor, S. E., and P. V. Fishback, 1996, "Precautionary Saving, Insurance, and the Origins of Workers' Compensation," The Journal of Political Economy, Vol. 104, No. 2, pp. 419-42.

Kirsanova, T., and J. Sefton, 2007, A Comparison of National Saving Rates in the U.K., U.S. and Italy," European Economic Review 51(8): pp. 1998-2028.

Kotlikoff, L. J., 1989, What Determines Savings? MIT Press Books, The MIT Press.

Kraay, A., 2000, "Household Saving in China," The World Bank Economic Review 14(3): pp.545-70.

Leetmaa, P., H. Rennie, and B. Thiry, 2009, "Household Saving Rate Higher in the EU than in the USA Despite Lower Income," Eurostat, Statistics in Focus 29.

Loayza, N., K. Schmidt-Hebbel, and L. Serven, 2000, "What Drives Private Saving Across the World?" The Review of Economics and Statistics 82(2): pp.165-81.

McKinsey Global Institute, 2009, If you've Got it, Spend it: Unleashing the Chinese Consumer.

Modigliani, F., and S. Cao, 2004, “The Chinese Saving Puzzle and the Life-Cycle Hypothesis," Journal of Economic Literature 42(1): pp.145-70.

OECD, 2009a, OECD Economic Outlook Database, OECD, Paris.

OECD, 2009b, OECD Social Expenditure Database, OECD, Paris.

Park, D., and K. Shin, 2009, "Saving, Investment, and Current Account Surplus in Developing Asia," Asian Development Bank Economics Working Paper Series No.158.

Prasad, E., 2009, “Rebalancing Growth in Asia,” IZA Discussion Paper No. 4298.

Wei, S., and X. Zhang, 2009, "The Competitive Saving Motive: Evidence from Rising Sex Ratios and Saving Rates in China," NBER Working Paper No. 15093.

World Bank, 2009, World Development Indicators, World Bank. 